\title{
22: $41831255-41850216$
}

National Cancer Institute

\section{Source}

National Cancer Institute. 22:41831255-41850216. NCI Thesaurus. Code C41774.

Physical location of BIK_Gene 